\title{
Digital and Cashless Economy on Msmes -A Special Reference with Peenya Industrial Area, Bengaluru
}

\author{
K. Uma Maheswari, T. Danalakshmi
}

\begin{abstract}
Organized sectors are already familiar with digital economy through banking one way or other. Micro, Small and Macro Enterprises (MSMEs) may or may not have bank account due to their level of transactions and the ways they do their business, make them to continue to remain in the SME sector and not scale beyond a point. So a good percentage of this Group of people is unbanked and away from digital economy. Micro and SMEs are generating employment and helps for the promotion of the large scale sectors' development especially for the rural India. This study was made an attempt to analyse the impacts on digital and cashless economy of MSMEs in Peenya Industrial Area, Bengalure.
\end{abstract}

Key Words: Digital and Cashless Economy, MSMEs, Peenya Industrial Area.

\section{INTRODUCTION}

Poverty reduction and inclusive growth are the prime aim of any welfare state. Micro, Small and Macro Enterprises (MSMEs) contribute more for the reduction of poverty through its employment. If, it upgrades its technology and works under digital economy, our country achieves inclusive growth. Digital technology should be regarded as a power multiplier or a "levelling up" mechine for MSMEs1. The CII KPMG report said that, "Digital technology has opened a plethora of avenues for small business owners and entrepreneurs to reach out to its customers to create an impact, innovate and grow. However, between operating on a restricted budget, limited resources and growing revenue, entrepreneurs are faced with various challenges on marketing". Digital economy is where financial transactions are being done by digital currencies by electronic digital form. Cashless economy is an economic system where small amount of cash is used in transactions and the main transactions made by credit cards, debit cards, wallets or digital modes. The concept of digital and cashless economy is that to make people use digital payment methods for their transaction of money for goods and services2.. After demonetisation the people are moving towards cashless economy using digital payments. Everyone from small merchant to neighbouring vegetable vendors all is using digital payment system3.

The main advantage of the digital and cashless economy is it avoids the risk of cash carrying in everywhere which reduces the theft. It also makes all transactions accountable and increases the tax revenue of government and helps to track the illegal money easily. Limited cash transactions

Revised Manuscript Received on September 10, 2019.

Dr. K. Uma Maheswari., M.Com., MBA., Ph.D., Associate Professor,

Centre for PG Studies, Sindhi College, Bengaluru,Karnataka, India.

(email: umameenaxi@gmail.com)

Dr. T. Danalakshmi, M.Com., M.Phil,, Ph.D., Head, Commerce Department, J.H.A.Agarsen College, Chennai, Tamilnadu, India.

(email: danalakshmirajesh.dr@gmail.com) control the inflation rate. Digital and cashless transactions provide easy trade and economic freedom around the world. There are many problems to follow cashless economy in India; most of the people are not having the knowledge of doing digital transactions with less income level who finds it difficult to use the digital payments.

Micro, Small and Macro Enterprises (MSMEs) may or may not have such account due to their level of transactions and the way they do their business make them to continue to remain in the SMEs sector and not scale beyond a point. So a good percentage of this Group of people is unbanked and away from digital economy. They may also not be literate enough to master the technology. Further, micro and SMEs create competitive market pressure, while they also play important role as sub-contractors in the down-sizing, privatisation and restructuring of large enterprises. The employers are not able to withdraw money or make transaction above certain limit.

\section{STATEMENT OF THE PROBLEM}

In India, most of the transactions are in cash; nearly $90 \%$ of the stores in the market are accepting money4. Micro and small scale enterprises not only contribute significantly to improved living standards, they also bring about substantial local capital formation and achieve high levels of productivity and capability. SMEs are the backbone of larger corporate and institutions who might be executing some of these big bang infrastructure projects. SMEs will have to embrace the digital economy to leverage the benefits accruing in the form of improved productivity, credit based on transaction history and exercise greater transparency in their businesses. Peenya lies in Bengaluru and it is one of the biggest industrial areas in Asia5. It houses Micro, Small, Medium and Large Scale Industries. These enterprises play a vital role in the economic growth of the country. In this situation this study takes the initiation to analyse the impact of digital and cashless economy on Micro and SMEs as they are one of the major players in the economic development of any industrial areas like Peenya in Bengaluru North.

\section{OBJECTIVES OF THE STUDY}

1. To find the awareness about the digital and cashless economy, on the Micro and SMEs in Peeniya, Bengaluru North.

2. To find the impact of the digital and cashless economy on the Micro and SMEs. 
3. To suggest some ways and means for the promotion of digital and cashless economy to the Micro and SMEs for the furthermore development.

\section{HYPOTHESIS}

H0: There is no significant difference between MSMEs in the impact level on digital and cashless economy.

\section{SCOPE OF THE STUDY}

The present study focuses on the digital and cashless economy of Micro and SMEs of Peenya Industrial Area, Bengaluru North. This study covers the awareness of the Micro and SMEs about the digital and cashless economy and impacts of the economical change by the Indian Government on the digitalisation.

\section{METHODOLOGY}

The research design adopted in this study was a blend of analytical and descriptive in nature. Population of this study has comprised Micro, Small and Medium Scale Enterprises (MSMEs) registered under Peenya Industrial Association (PIA) in North Bengaluru. This study has collected data from the registered members of PIA. Convenient sampling method was used to collect the data. In this method 50 registered Enterprises from each scale (Micro, Small \& Medium) were taken for data collection. With the help of literature review, questions were framed on awareness and the impacts of digital and cashless economy in MSMEs. And the responses to these questions were collected using interview schedule method. Data were analysed by using statistical tools such as frequency, percentage and one way ANOVA.

\section{ANALYSIS AND INTERPRETATION RESULTS}

This study has collected 150 MSMEs personal data like the companies' establishment, about digital users, problems faced by the companies and government support for their development were presented in Table No. 1.

TABLE 1

PARTICULARS ABOUT THE ORGANISATIONS

\begin{tabular}{|c|c|c|c|}
\hline Particulars & Variables & frequency & Per cent age \\
\hline \multirow{4}{*}{ Organis ation type } & Micro & 50 & 33.30 \\
\cline { 2 - 4 } & Small & 50 & 33.30 \\
\cline { 2 - 4 } $\begin{array}{c}\text { Year of } \\
\text { establishment }\end{array}$ & Medium & 50 & 33.40 \\
\cline { 2 - 4 } & Up to 5 years & 19 & 12.67 \\
\hline \multirow{3}{*}{$\begin{array}{c}\text { Using digital and } \\
\text { cashless economy years }\end{array}$} & $11-15$ years & 48 & 32.00 \\
\cline { 2 - 4 } & $15-20$ years & 30 & 20.00 \\
\cline { 2 - 4 } $\begin{array}{c}\text { Government } \\
\text { support }\end{array}$ & Above 20 years & 20 & 22.00 \\
\cline { 2 - 4 } & Yes & 77 & 13.33 \\
\hline Problems faced by & Yes & 73 & 51.00 \\
\cline { 2 - 4 } the organis ation & No & 105 & 49.00 \\
\cline { 2 - 4 } & No & 90 & 30.00 \\
\hline
\end{tabular}

In order to determine the impacts of digital and cashless economy in MSMEs, null hypothesis was framed and tested as follows

There is no significant difference between MSMEs in the impact level on digital and cashless economy.

\section{TABLE 2}

LEVEL OF IMPACT ON DIGITAL AND CASHLESS ECONOMY AMONG MSMES

\begin{tabular}{|c|c|c|c|c|c|c|c|c|}
\hline \multirow{2}{*}{ Impact on } & $\begin{array}{c}\text { Type of } \\
\text { Organisation }\end{array}$ & $\mathbf{N}$ & Mean & S.D & $\begin{array}{c}\text { Source } \\
\text { of } \\
\text { Variance }\end{array}$ & $\begin{array}{c}\text { Mean } \\
\text { Square }\end{array}$ & 'F' & Sig. \\
\hline \multirow{2}{*}{$\begin{array}{c}\text { Digital and } \\
\text { Cashless } \\
\text { Economy }\end{array}$} & Micro & 50 & 2.89 & 0.40 & Between & 2.269 & \multirow{2}{*}{9.002} & \multirow{2}{*}{$\mathbf{0 . 0 0 0}$} \\
\cline { 2 - 6 } & Small & 50 & 2.47 & 0.66 & Groups & \\
\cline { 2 - 6 } & Medium & 50 & 2.64 & 0.39 & Within & 0.251 & \\
\cline { 2 - 6 } & Total & 150 & 2.67 & 0.53 & Groups & & \\
\hline
\end{tabular}

In the above Table 2, it was found that ' $p$ ' value (level of significance) was less than 0.05 at 2 degrees of freedom. So the hypothesis was rejected and the study proved that the impacts of digital and cashless economy on all three types of organisation were differing. It was found that there was a significant difference between the type of organisation and impact on digital and cashless economy. The Medium scale industries were not impacted owing to digital and cashless economy as their Standard Deviations (SD) was less compared to Micro and Small Enterprises. This was because their level of transactions was high and most of the Medium Enterprises were using the digital payment system.

\section{FINDINGS}

The following were the major findings of the study:-

$>$ This study has comprised 86 per cent of the companies have been functional for more than 5 years. The main functions of such industries have been to supply spare parts to large scale industries. Thus the growth of MSMEs has raised parallel to the growth of large scale industries.

$>\quad$ Only 30 per cent of the companies were getting Government supports like tax exemption, loans (Rs.10 Lakhs from MUDRA) from Banks SIDBI and subsidies as the name of MSMEs. This is because of poor knowledge about Government Schemes. 60 per cent of the MSMEs were facing financial, marketing, and technical problems.

$>\quad$ This study has found that the digital and cashless economy affected the Micro and small enterprises deficiently, and no or little effect on medium level enterprises. Because medium enterprises were already turned into digital and cashless economy. Because most of their transactions were digitalised and their customers were large scale industries and exporters. This study has revealed that 65 per cent of the industries have been affected by demonetization due to the shortage of cash flow and difficulty in cash withdrawal resulting in hindrance in the continuity of the business

$>\quad$ Only 51 per cent of the enterprises were using the digital payment system for their transactions as these enterprises indulge in more credit base sales and have lesser transactions as bank transaction costs are high. 
> Only 40 per cent of the MSMEs were well aware and have sensitized the adaptation of the digital and cashless policy and this is because of their business relations with large scale industries.

$>\quad$ Digital payments system was affected the growth of 60 per cent of Micro and Small scale industries as their transaction cost, maintenance cost, GST (payment within a month) which were very high and complex. 75 per cent of the Micro and Small scale industries were following the informal credit system of transaction, which needed cash operations.

\section{SUGGESTIONS}

The study suggests few measures which can be undertaken by the government to make the MSMEs move towards digital payment.

* The Government has to provide low 'switching cost' to encourage digital and cashless transaction apart from, easy credit accessibility by reducing formalities for loan sanction and tax relaxation for a minimum period which encourage MSMEs to move towards a cashless economy.

* The Government has to provide platform for improving digital and cashless economy in the healthy competitive way among the MSMEs by regulatory frame works, will accelerate the adoption of digital transactions in day-to-day business transactions.

* The Government should also educate the MSMEs through their associations to enhance the awareness of digital and cashless economy and the reliability by ensuring secured transactions and its.

* Conducting vigorous campaign on the facilities provided by the government for MSMEs and ensures the effective utilization of such facilities for the sustainability of such business will encourage them to adopt digital and cashless economy for all their business transactions.

* Peenya Industrial Association has to help its member by giving awareness about the government policies related to MSMEs and getting them loan facilities provided by the banking sectors.

\section{CONCLUSION}

Digital economy is inevitably important for the MSMEs, for its growth of the global level ecosystem. These industries assist the large scales industries by manufacturing spares and help for the economical growth. Digital and cashless economy reduces the time and cost in the multilevel business transactions and it enhances the business efficacy. The existence and continuity of digital and cashless economy are unavoidable for the socio economic development and welfare state. But, it needs legal regulation and proper implementation. With the harmonization of government and MSME Industries makes this digital and cashless economy in the systematic way and helps for the financial inclusion.

\section{REFERENCES}

1. Capri, A. (2017). Micro And Small Businesses In Indonesia's Digital Economy. Indonesia: Indonesia's
Commission For The Supervision Of Business Competition.

2. Dr. Budheshwar Prasad Singhraul, Yogita Satish Garwal. "Cashless Economy - Challenges and Opportunities in India." Pacific Business Review International, Volume 10 Issue 9, March 2018: pg 54-63.

3. Podile*, Dr. Venkateswararao, and P. Rajesh. "Public Perception on Cashless Transactions in India." Asian Research Consortium, Vol. 7, No. 7, July 2017, pp. 63 77.

4. Syamsundar P, S. E. (January 2017). "Demonetization A Comparative Study" With Special Reference To India. Research Gate.

5. Ranganna, T. (Jun 29, 2005). Lack of infrastructure dogs Peenya industrial estate. Karnataka, Bangalore: The Hindu, Online edition. 